\title{
Cinnamomum zeylanicum bark essential oil induces cell wall remodelling and spindle defects in Candida albicans
}

\author{
Zinnat Shahina ${ }^{1}$, Amira M. El-Ganiny², Jessica Minion ${ }^{3}$, Malcolm Whiteway ${ }^{4}$, Taranum Sultana ${ }^{1{ }^{* \dagger}}$ \\ and Tanya E. S. Dahms ${ }^{1,3^{*}+}$
}

\begin{abstract}
Background: Cinnamon (Cinnamomum zeylanicum) bark extract exhibits potent inhibitory activity against Candida albicans but the antifungal mechanisms of this essential oil remain largely unexplored.

Results: We analyzed the impact of cinnamon bark oil on C. albicans RSY150, and clinical strains isolated from patients with candidemia and candidiasis. The viability of RSY150 was significantly compromised in a dose dependent manner when exposed to cinnamon bark oil, with extensive cell surface remodelling at sub inhibitory levels $(62.5 \mathrm{\mu g} /$ $\mathrm{mL}$ ). Atomic force microscopy revealed cell surface exfoliation, altered ultrastructure and reduced cell wall integrity for both RSY150 and clinical isolates exposed to cinnamon bark oil. Cell wall damage induced by cinnamon bark oil was confirmed by exposure to stressors and the sensitivity of cell wall mutants involved in cell wall organization, biogenesis, and morphogenesis. The essential oil triggered cell cycle arrest by disrupting beta tubulin distribution, which led to mitotic spindle defects, ultimately compromising the cell membrane and allowing leakage of cellular components. The multiple targets of cinnamon bark oil can be attributed to its components, including cinnamaldehyde (74\%), and minor components (<6\%) such as linalool (3.9\%), cinamyl acetate (3.8\%), a-caryophyllene (5.3\%) and limonene (2\%). Complete inhibition of the mitotic spindle assembly was observed in C. albicans treated with cinnamaldehyde at MIC $(112 \mu \mathrm{g} / \mathrm{mL})$.
\end{abstract}

Conclusions: Since cinnamaldehyde disrupts both the cell wall and tubulin polymerization, it may serve as an effective antifungal, either by chemical modification to improve its specificity and efficacy or in combination with other antifungal drugs.

Keywords: Cinnamomum zeylanicum, Candida albicans, Essential oil, Cell wall remodelling, Spindle defects

\section{Background}

Candida albicans, a commensal fungi, develops into a resilient pathogen under low host immunity such as that for immunocompromised individuals with HIV/ AIDS, and patients undergoing cancer chemotherapy [1-3]. A limited number of antifungals are available for treating such infections, and the use of these antifungal

\footnotetext{
*Correspondence: tanya.dahms@uregina.ca; taranum.sultana@uregina.ca 'Taranum Sultana and Tanya E. S. Dahms contributed equally to the design of experiments, student supervision and manuscript writing

${ }^{1}$ Department of Chemistry and Biochemistry, University of Regina, 3737

Wascana Parkway, Regina, SK, Canada

Full list of author information is available at the end of the article
}

classes, including azoles, echinocandins, polyenes and allylamines, can be accompanied by side effects. Poor bioavailability requires higher doses, which can ultimately result in resistance and ineffectiveness [4]. The continued high morbidity following systemic fungal infection and emerging resistance to antifungal agents underscore a clear need for alternatives [5]. In this context, essential oils (EOs) are gaining popularity due to their strong antimicrobial and antibiofilm activity $[6,7]$. EO combinations with other essential oils or existing antifungal agents could vastly reduce the probability of multi-drug resistance [6-11]. However, comprehensive studies are required to fully assess their independent 
pharmacological properties and potential side effects prior to consideration for clinical use as antifungal agents.

Cinnamon oil is an aromatic liquid obtained from the twigs, bark and leaves of Cinnamomum zeylanicum [12]. Extracts of cinnamon bark (CNB) and leaves $(\mathrm{CNL})$ have been used extensively as therapeutics in many cultures since antiquity. The anti-candida activity of $\mathrm{CNB}$ oil against planktonic and biofilm culture of $C$. albicans and non-albicans spp. has been documented [7, 13-15]. The main constituents of CNB oil include trans-cinnamaldehyde, and minor components such as eugenyl acetate, linalool, and benzyl benzoate, each having antifungal activity [16-20]. CNB oil has been shown to alter cell membrane permeability and fluidity, and inhibit biofilm formation $[7,13,15,21]$, but the mechanisms of toxicity remain unknown. On the other hand, each component has been extensively studied, showing effects at various cellular sites, including the cell membrane and cytosol. For example, cinnamaldehyde, the major constituent of CNB oil, targets the membrane and causes increased cell wall thickness in C. albicans [16], attributed to $\beta-1-$ 3 -glucan synthase inhibition as observed in Saccharomyces cerevisiae [22]. The increase in bud scar formation upon cinnamaldehyde exposure also suggests an impact on cell division, resulting in decreased viability [16, 23]. Benzyl benzoate and linalool affect membrane fluidity and induce cell cycle arrest at the G2-M and G1 phases, respectively [20] at concentrations greater than the minimum inhibitory concentration (MIC) $[7,16,17,23]$. We hypothesized that the cell wall and membrane are primary targets of CNB oil, which in turn disrupt intracellular processes vital to Candida survival.

Here, we report a detailed characterization of the anticandidal effects of CNB oil using atomic force microscopy (AFM), laser scanning confocal microscopy (LSCM) and traditional biochemical assays. AFM quantitative imaging $\left(\mathrm{QI}^{\mathrm{TM}}\right)$ is a powerful tool for assessing the impact of antifungals [24-28], nutrient stress [29], oxidative stress [30] and characterizing yeast genetic mutants [31], while LSCM imaging of fluorescent markers can delineate defects in intracellular processes. AFM was used to quantify the morphological, ultrastructural and biophysical properties of RSY150 and a clinical isolate exposed to CNB oil. The RSY150 strain of C. albicans with RFP tagged histone protein B (Htb-RFP) and GFP tagged $\beta$-tubulin (Tub2-GFP) was used to track cell cycle defects in response to CNB oil exposure. Finally biochemical assays were used to verify physiological changes identified by imaging. We report for the first time that $\mathrm{CNB}$ oil causes $\beta$-tubulin depolymerisation and cell cycle arrest, which we attribute to its major constituent cinnamaldehyde.

\section{Methods}

\section{Chemicals and media}

The cinnamon bark essential oil (Chemical Abstract Service (CAS), registry number 8015-91-6) was a steam distilled extract from the dried inner bark (Now foods, USA) of Cinnamon zeylanicum (cinnamon). Bacto ${ }^{\mathrm{TM}}$ agar, yeast extract and peptone were obtained from Difco (BD Biosciences, NJ, USA), and all other chemicals were purchased from Sigma Chemical Co. (St. Louis, MO, USA).

\section{CNB essential oil analysis}

$\mathrm{CNB}$ oil was analyzed using gas chromatographyflame ionization detection (GC-FID) and gas chromatography-mass spectrometry (GC-MS) with an Agilent 7890A GC according to previously reported methods [32, 33]. Briefly, $1 \mu \mathrm{l}$ of diluted CNB oil (1:10 in ethanol) was injected onto a HP-5 column $(30 \mathrm{~mm} \times 0.32 \mathrm{~mm} \times 0.25 \mu \mathrm{m})$ and separated using a carrier gas of helium (constant flow of $1.1 \mathrm{~mL} / \mathrm{min}$ ) with the following temperature gradient: $60{ }^{\circ} \mathrm{C}$ for $5 \mathrm{~min}$, increased to $210{ }^{\circ} \mathrm{C}$ at $3{ }^{\circ} \mathrm{C} / \mathrm{min}$ and to $260{ }^{\circ} \mathrm{C}$ at $10{ }^{\circ} \mathrm{C} /$ min. The GC-FID injector and detector temperatures were $250^{\circ} \mathrm{C}$ and the split ratio of injection was 20:1. For GC-MS using similar conditions, $0.2 \mu \mathrm{l}$ was injected with a split ratio of 200:1 and separated on a HP-5MS column (30 $\mathrm{mm} \times 0.25 \mathrm{~mm} \times 0.25 \mathrm{um})$.

Retention indices (RI) were determined using a C8-20 standard ( $40 \mathrm{mg} / \mathrm{L}$ each, in hexanes) for both the GCFID and GC-MS methods. RI values were averaged between the methods for each component of the oil and identified using the NIST14 database and reported literature [32, 34].

\section{Strains and culture conditions}

Candida albicans strains and clinical isolates used in this study are described in Table 1. The RSY150 and RSY35 strains were a kind gift of Dr. Richard J. Bennett. RSY150 expresses Tub2-GFP and Htb-RFP and RSY35 is a Kar3 deletion mutant that express only Tub2-GFP [35]. Kar3 is a bifunctional protein having a kinesin-like motor domain joined to a distinct microtubule binding domain that is essential for yeast nuclear fusion during mating [36]. Strains were stored as $50 \%$ glycerol stocks at $-80{ }^{\circ} \mathrm{C}$ and were freshly revived on yeast-extract peptone dextrose agar (YPDA) containing 1\% Bactoyeast extract, $2 \%$ Bacto-peptone, $2 \%$ glucose and $2 \%$ Bacto-agar prior to each experiment. All strains were grown with continuous shaking $(200 \mathrm{rpm})$ at $30{ }^{\circ} \mathrm{C}$ in YPD broth and the mutant strains supplemented with $80 \mathrm{mg} / \mathrm{L}$ uridine (YPDU). For the yeast to hyphal transition and leakage assays, cells were grown to mid log phase before exposure to CNB oil. For hyphal induction 
Table 1 Candida albicans strains used in this study

\begin{tabular}{|c|c|c|}
\hline Strain & Genotype & References \\
\hline RSY150 & TUB2-GFP-SAT1/TUB2_HTB1-RFP-ARG4_/HTB1_arg4_/_ & {$[35]$} \\
\hline RSY35 & $\begin{array}{l}\text { leu2::hisG/leu2::hisG his1::hisG/his1::hisG arg4::hisG/arg4::hisG kar3::LEU2/kar3::HIS1 TUB2/TUB2- } \\
\text { GFP::SAT1 }\end{array}$ & {$[35]$} \\
\hline CASS1 & his3::hisG/his3::hisGleu2::tetRGAL4AD-URA3/LEU2 & {$[37]$} \\
\hline ATCC 64548 & Reference strain & Cedarlane Labs, Ontario, Canada \\
\hline ATCC 10231 & Reference strain for clinical isolates & RQHR, Regina, \\
\hline \multicolumn{3}{|l|}{ SK, Canada } \\
\hline \multirow[t]{2}{*}{ C. albicans (1-4) } & Clinical isolates; 2 blood, 2 genital & RQHR, Regina, SK, Canada \\
\hline & C. albicans knockout mutants & \\
\hline VPS28 & his3::hisG/his3::hisGleu2::tetRGAL4AD-URA3/LEU2-VPS28 & {$[37]$} \\
\hline $\mathrm{CRH} 11$ & his3::hisG/his3::hisGleu2::tetRGAL4AD-URA3/LEU2-Crh11 & {$[37]$} \\
\hline SSU81 & his3::hisG/his3::hisGleu2::tetRGAL4AD-URA3/LEU2-SSU81 & {$[37]$} \\
\hline DFG5 & his3::hisG/his3::hisGleu2::tetRGAL4AD-URA3/LEU2-DGF5 & {$[37]$} \\
\hline
\end{tabular}

experiments, cells were grown in YPD broth with $10 \%$ fetal bovine serum and $2 \%$ glucose.

\section{Minimum inhibitory concentration (MIC)}

The MIC of CNB oil was determined for all strains listed in Table 1 following the guidelines of the Clinical and Laboratory Standards Institute [CLSI 2014] [38] and previously reported method [15], with slight modifications. Briefly, $100 \mu \mathrm{l}$ of CNB oil (stock concentration $1000 \mu \mathrm{g} /$ $\mathrm{mL}$ ) was serially diluted in triplicate in the wells of flatbottom polystyrene 96-well microtiter plates (Sarstedt, Nümbrecht, Germany). A suspension $\left(\mathrm{OD}_{600}=0.001\right)$ of C. albicans $\left(2.2 \times 10^{5}\right.$ cells $\left./ \mathrm{mL}\right)$ in YPD was added, with appropriate positive (amphotericin B) and negative (Candida only in media) controls and a blank (CNB oil in media) included. The microtiter plates were sealed with parafilm prior to incubation at $30{ }^{\circ} \mathrm{C}$ to avoid oil evaporation, and the $\mathrm{OD}_{600}$ recorded after $24 \mathrm{~h}$ (Biotek Epoch; Northern Vermont, USA). The endpoint was defined as the lowest concentration of the compound resulting in total inhibition (MIC 100\%) of growth, compared to the growth in negative control wells. All experiments were performed in triplicate. The MICs for cinnamaldehyde (stock concentration $450 \mu \mathrm{g} / \mathrm{mL}$ ) and linalool (stock concentration $9.85 \mathrm{mg} / \mathrm{mL}$ ) were also tested for RSY150 and RSY35 [16, 39, 40].

\section{Growth and viability of C. albicans with CNB oil exposure Growth curves}

To investigate the effect of $\mathrm{CNB}$ oil on growth kinetics of $C$. albicans, an overnight culture of $C$. albicans RSY150 diluted to contain $2.2 \times 10^{5}$ cells $/ \mathrm{mL}\left(\mathrm{OD}_{600}\right.$ of 0.001$)$ was treated with $\mathrm{CNB}$ oil $(62.5,31.25$ and $15.1 \mu \mathrm{g} / \mathrm{mL}$ corresponding to $1 / 2 \mathrm{MIC}, 1 / 4 \mathrm{MIC}$ and $1 / 8$
MIC) in separate wells of a microtiter plate in triplicate and incubated at $30{ }^{\circ} \mathrm{C}[41,42]$. The $\mathrm{OD}_{600}$ was measured at $30 \mathrm{~min}$ intervals for $24 \mathrm{~h}$ using a BioTek Synergy HTX multi-mode microplate reader (Northern Vermont, USA). Media with CNB oil was used to determine background absorbance for three independent experiments.

\section{Cell viability}

The cell viability after $\mathrm{CNB}$ oil exposure was determined using the methylene blue dye exclusion assay, as reported previously [43]. Briefly, mid logarithmic phase C. albicans RSY150 cultures $\left(2.2 \times 10^{5}\right.$ cells $\left./ \mathrm{mL}\right)$ were treated with various concentrations $(62.5,31.25$ and $15.1 \mu \mathrm{g} / \mathrm{mL}$ corresponding to $1 / 2 \mathrm{MIC}, 1 / 4 \mathrm{MIC}$ and $1 / 8 \mathrm{MIC}$ ) of $\mathrm{CNB}$ oil at $30^{\circ} \mathrm{C}$ for $24 \mathrm{~h}$. Cells fixed with formaldehyde were used as positive controls for staining. The cells were washed and resuspended in phosphate buffered saline (PBS;0.01 M pH 7.4) to $\sim 10^{7} \mathrm{CFU} / \mathrm{mL}$, then $100 \mu \mathrm{L}$ of treated and control cell suspensions mixed with $100 \mu \mathrm{L}$ methylene blue $(0.1 \mathrm{mg} / \mathrm{mL}$ stock solution in $2 \%$ sodium citrate) and incubated for $5 \mathrm{~min}$ at room temperature. Cells were examined using an Eclipse 80i microscope (Nikon) at $40 \times$ magnification. A minimum of 100 cells in consecutive visual fields were examined and the percentage of stained cells were calculated using the Nikon SPOT software [44].

To determine colony forming units (CFU), overnight cultures of CNB oil-treated C. albicans RSY150 (1/2 MIC, 1/4 MIC, and 1/8 MIC) along with controls were serially diluted $\left(10^{3}, 10^{4}, 10^{5}\right.$ cells $\left./ \mathrm{mL}\right)$ and plated in duplicate on YPD agar [45]. Viable colonies were counted and recorded at each specific concentration of CNB oil prepared in triplicate. 


\section{Morphological analysis}

Calcofluor white $(\mathrm{CFW})$ at a concentration of $0.01 \mu \mathrm{g} /$ $\mathrm{mL}$ was used as a chitin specific dye [35] to highlight the gross morphology and chitin distribution in CNB oil treated RSY150 along with blood and genital clinical isolates. Cell suspensions at two growth phases each, mid logarithmic $\left(1 \times 10^{7}\right.$ cells $\left./ \mathrm{mL}\right)$ and stationary $\left(2.2 \times 10^{5}\right.$ cells $/ \mathrm{mL}$ ), were treated with MIC and $1 / 2 \mathrm{MIC}$ of CNB oil and imaged on an Axio Observer Z1 inverted epifluorescence microscope (Oberkochen, Germany) at $63 \times$ magnification $\left(\lambda_{\mathrm{ex}}=365 \mathrm{~nm} ; \lambda_{\mathrm{em}}=435 \mathrm{~nm}\right)$.

\section{Hyphal induction}

Hyphal induction in C. albicans RSY150 was performed according to the literature [46]. Briefly, a yeast suspension $\left(1 \times 10^{7} \mathrm{CFU} / \mathrm{mL}\right)$ was prepared from mid logarithmic phase cells in pre-warmed YPD with $10 \%$ fetal bovine serum (FBS) and deposited into a 12 well plate with the appropriate amounts of CNB oil to achieve MIC and 1/2 MIC. Control cultures lacked CNB oil. The cells were stained with CFW $(0.01 \mu \mathrm{g} / \mathrm{mL})$ to highlight hyphae and pseudo hyphae after $4 \mathrm{~h}$ incubation at $37{ }^{\circ} \mathrm{C}$, and images captured on an AxioObserver Z1 inverted epifluorescence microscope (Oberkochen, Germany). Germ tubes were identified when the cell projection was equal to the size of the blastospore. Results from three independent experiments were reported as average \pm standard deviation.

\section{Ultrastructural and mechanical analysis}

The cell surface biophysical properties of CNB oil treated C. albicans RSY150 and a clinical isolate from blood were analyzed by Quantitative Imaging $\left(\mathrm{QI}^{\mathrm{TM}}\right)$ using a Nanowizard III AFM (JPK Instruments, Berlin, Germany) as described previously $[47,48]$. Briefly, cell suspensions $\left(2.2 \times 10^{5}\right.$ cells $\left./ \mathrm{mL}\right)$ from both strains treated either with YPD only (control) or YPD with $1 / 2$ MIC CNB oil for $24 \mathrm{~h}$ were deposited onto poly-L-Lysine coated cover slips for $1 \mathrm{~h}$, fixed with formalin and air dried prior to AFM imaging. Cells treated with the fungal wall degrading enzyme, glucanase, served as a positive control. Samples were imaged with silicon nitride cantilevers (HYDRA6R-200NG; Nanosensors, Neuchatel, Switzerland) having calibrated spring constants ranging from 0.03 to $0.062 \mathrm{~N} / \mathrm{m}$.

QI force curves (JPK software) obtained at each pixel of a $128 \times 128$ raster scan were collected using a Z-length of $7 \mu \mathrm{m}$ and a raster scan of $100 \mu \mathrm{m} / \mathrm{s}$ for $\mathrm{QI}^{\mathrm{TM}}$. Adhesion and Young's modulus calculations were made from approximately 16,536 force curves collected from each of five biological replicates. All force curves within a $200 \times 200 \mathrm{~nm}$ square in the center of the cell were batch processed and histogram data exported from the JPK software using Excel. Adhesion was determined using the distance between the lowest point and baseline of the retract curve and Young's moduli determined using the Hertz model (JPK software), an estimate of cell envelope elasticity. Surface roughness was measured at the midpoint of the cell using the $\mathrm{QI}^{\mathrm{TM}}$ height images [48] and cellular volume was calculated using "Ellipsoid" (http:// planetcalc.com/) [49] for at least 20 different cells from three different samples.

\section{Membrane integrity}

To assess the integrity of the cell membrane following CNB oil exposure, the cellular content leakage assay [43] was carried out with slight modification. Briefly, a mid logarithmic phase culture of $C$. albicans RSY150 was washed three times and resuspended to $\sim 10^{7} \mathrm{CFU} / \mathrm{mL}$ in PBS. Cell suspensions were transferred to a 24 well plate containing CNB oil at MIC, $1 / 2,1 / 4$ and $1 / 8$ MIC in PBS, and incubated at $30{ }^{\circ} \mathrm{C}$ for $6 \mathrm{~h}$ with shaking (200 rpm). CNB oil in PBS served as a blank, untreated cells in PBS as negative controls, and amphotericin B at MIC served as a positive control. Following incubation, cell leakage was analyzed from supernatant diluted 1:10 with PBS based on absorbance at $260 \mathrm{~nm}$ (Varian Cary $100 \mathrm{BIO}$, UV-VIS spectrophotometer; Midland, ON, Canada) against a blank lacking CNB oil. Nucleotides represent one class of leakage components that absorb at $260 \mathrm{~nm}$, for which uracil containing compounds have the highest absorbance. Mean ratios for each treatment from three independent experiments were calculated and compared to that of corresponding untreated samples.

\section{Cell wall stress}

The sensitivity of $C$ albicans to cell wall perturbing agents (Congo red (CR) and CFW) after exposure to CNB oil was tested following a previously reported method [6], with minor modifications. Briefly, overnight stationary phase cultures of C. albicans RSY150 $\left(2.2 \times 10^{5}\right.$ cell/ $\mathrm{mL}$ ) in YNB complete media, unexposed or exposed to CNB oil at $1 / 2$ MIC and 1/4 MIC, were incubated for $24 \mathrm{~h}$ with shaking $(200 \mathrm{rpm})$ at $30^{\circ} \mathrm{C}$ in a microtiter plate. Cells were washed with PBS to eliminate oil residues and any carryover effect of the oil to different wells. An aliquot $(5 \mu \mathrm{L})$ of each was diluted to final densities of $10^{5}$, $10^{4}, 10^{3}$ cells $/ \mathrm{mL}$ and were spotted on YNB plates supplemented with one of the following cell wall disrupting agents: CFW $(15 \mu \mathrm{g} / \mathrm{mL})$ or CR $(15 \mu \mathrm{g} / \mathrm{mL})$. The plates were incubated at $30{ }^{\circ} \mathrm{C}$ and monitored for Candida growth over 3 days. Each experiment was performed in triplicate and colonies counted for statistical analysis and graphical representation. 


\section{Confocal microscopy}

The effects of CNB oil treatment on the cell cycle was determined by laser scanning confocal microscopy (LSCM) [35]. RSY150 cells expressing Tub2-GFP and Htb-RFP [35] at mid logarithmic phase $\left(10^{7}\right.$ cells $\left./ \mathrm{mL}\right)$ were treated with $\mathrm{CNB}$ oil, cinnamaldehyde and linalool at MIC and 1/2 MIC for $4 \mathrm{~h}$. Treated and control cells were transferred to glass slides sealed with clean coverslips and imaged at $63 \times$ magnification on a Zeiss LSM 780 system (Carl Zeiss Micro imaging, Oberkochen, Germany) using an argon laser $\left(\lambda_{\mathrm{ex}}=488 \mathrm{~nm} ; \lambda_{\mathrm{em}}=512 \mathrm{~nm}\right)$ for Tub2-GFP and HeNe laser $\left(\lambda_{\mathrm{ex}}=543 \mathrm{~nm} ; \lambda_{\mathrm{em}}=605 \mathrm{~nm}\right)$ for Htb-RFP. Cells were identified and enumerated in each cycle phase category. Statistical significance was calculated from three independent experiments.

\section{Statistical analysis}

All experiments were performed in triplicate, unless otherwise stated, and GraphPad Prism7 used for statistical analysis. The results were reported as mean \pm standard deviation (SD), differences assessed using a two-tailed unpaired $t$ test with Welch's correction at a 95\% confidence interval, for which $\mathrm{p}<0.05$ was considered statistically significant.

\section{Results}

\section{CNB oil composition}

CNB oil analyzed by GC-FID and GC-MS identified several known constituents. The peaks identified by GC-FID were further confirmed with GC-MS and previously reported RI [32, 34]. The composition of our CNB is shown in Additional file 1: Table S1 (see Additional file 2: Figure S1), for which compounds are listed in the order of elution on the HP-5 column. The major compounds (concentrations $>2.0$ as relative \% peak area from GC-FID and GC-MS) were E-cinnamaldehyde (74\%), $\alpha$-caryophyllene (5.3\%), linalool (3.9\%) and E-cinnamyl acetate (3.8\%). Minor components with known function included limonene $(2 \%)$, eugenyl acetate $(0.6 \%)$, $\alpha$-pinene $(0.3 \%)$ and benzyl benzoate $(0.6 \%)$. Another minor constituent was p-cymene (1.4\%).

\section{RSY150 and clinical isolates of C. albicans respond} differently to CNB oil

The relative susceptibilities of the RSY150 strain and clinical isolates to $\mathrm{CNB}$ oil were determined using a broth microdilution method. The planktonic growth of C. albicans lab strains (ATCC 64548 and RSY150) was effectively inhibited by $125 \mu \mathrm{g} / \mathrm{mL} \mathrm{CNB}$ oil, whereas the clinical strain isolated from blood and the ATCC 10231 strain were more resistant and required higher concentrations $(250 \mu \mathrm{g} / \mathrm{mL})$ of CNB oil to produce an inhibitory effect. This clinical strain isolated from blood was selected for detailed analysis and further experiments. Clinical isolates from blood and genital infections displayed varying susceptibility to $\mathrm{CNB}$ oil. In general, a blood isolate was resistant to CNB oil with a MIC of $500 \mu \mathrm{g} / \mathrm{mL}$, whereas one genital strain was more resistant to $\mathrm{CNB}$ oil with a MIC at $1000 \mu \mathrm{g} / \mathrm{mL}$ and the other more susceptible with a MIC of $125 \mu \mathrm{g} / \mathrm{mL}$. The data is summarized in Table 2. RSY35, a mutant strain for microtubule motor protein Kar3, showed growth inhibition at $125 \mu \mathrm{g} / \mathrm{mL}$ of CNB oil. Similarly, the growth of RSY150 and RSY35 was inhibited by cinnamaldehyde with a MIC of $112.5 \mu \mathrm{g} / \mathrm{mL}$. Both strains showed identical response to linalool with MICs at $2.46 \mathrm{mg} / \mathrm{mL}$.

\section{Dose dependence of C. albicans RSY150 growth, viability and membrane integrity}

To determine the dose dependence of CNB oil over a $24 \mathrm{~h}$ period, growth curves were constructed at different concentrations of CNB oil $(15.625-125 \mu \mathrm{g} / \mathrm{mL})$ in YPD media. Growth inhibition was dose dependent with complete inhibition of growth at MIC $(125 \mu \mathrm{g} / \mathrm{mL})$ and increased growth at progressively lower sublethal concentrations: $62.5 \mu \mathrm{g} / \mathrm{mL}$ (1/2 MIC), $31.25 \mu \mathrm{g} / \mathrm{mL}(1 / 4$ $\mathrm{MIC}$ ) and $15.625 \mu \mathrm{g} / \mathrm{mL}$ (1/8 MIC) (Fig. 1a), used for subsequent experiments.

The viability of cells cultured to logarithmic phase after treatment for $4 \mathrm{~h}$ with different concentrations of $\mathrm{CNB}$ oil $(125-62.5 \mu \mathrm{g} / \mathrm{mL})$ were assessed using the vital dye, methylene blue (Fig. 1b), which enters both live and dead cells. Since live cells are able to reduce the dye $[50,51]$ they become colorless, whereas dead cells remain blue. The cells were non-viable following $\mathrm{CNB}$ oil treatment, confirmed

Table 2 Number of reference and clinical strains at various MIC values

\begin{tabular}{|c|c|c|c|c|c|c|}
\hline CNB oil $(\mu \mathrm{g} / \mathrm{ml})$ & Blood & Genital & RSY150 & RSY35 & ATCC 10231 & ATCC 64548 \\
\hline 1000 & & 1 & & & & \\
\hline 500 & 1 & & & & & \\
\hline 250 & $*_{1}$ & & & & & \\
\hline 125 & 3 & $* * 1$ & 1 & 1 & 1 & 1 \\
\hline
\end{tabular}

*Used as representative clinical strain in all further experiments

**Tested for chitin staining 


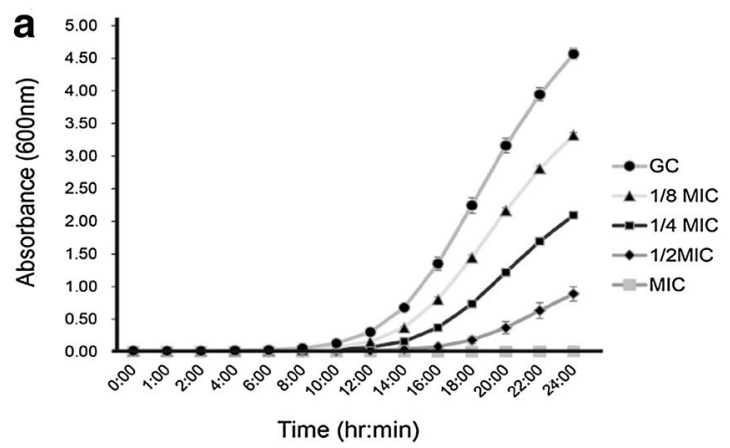

C

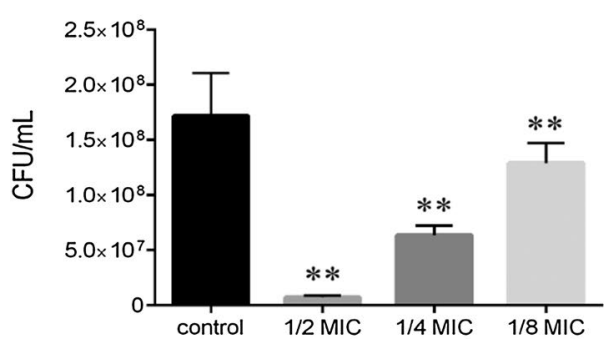

b


Fig. 1 CNB oil decreased cell viability and compromised cell membrane integrity in RSY150. a Growth curves of RSY150 exposed to 125, 62.5, 31.25 and $15.125 \mu \mathrm{g} / \mathrm{mL}$ of CNB oil, with absorbance measured at 30 min intervals to show the antifungal time course of the CNB oil. b Methylene blue staining of cells exposed to CNB concentrations as in (a) showed decreased cell viability. c Corresponding CFU counts of viable CNB exposed cells as compared to control. d Leakage of cellular content as a function of absorbance at $260 \mathrm{~nm}$ following exposure to CNB oil at concentrations as in (a) confirm a dose dependent compromise of the cell membrane in (a). GC indicates growth controls of cells incubated without CNB oil. Double asterisks represent statistical significance $(p<0.05)$

by CFU for each CNB oil treatment $(1 / 2,1 / 4$ and $1 / 8 \mathrm{MIC}$ and control). There was a significant reduction in the number of colonies treated with $1 / 2 \mathrm{MIC}$ CNB oil in comparison to cells treated at 1/4,1/8 MIC and control (Fig. 1c).

Membrane disruption in CNB oil treated RSY150 cells was assessed as leakage of cellular contents $\left(\mathrm{OD}_{600}=260 \mathrm{~nm}\right)$ in the supernatant [43]. The amount of leaked cellular content increased as a function of $\mathrm{CNB}$ oil concentration, from 1/8 MIC to MIC (Fig. 1d), showing that compromised cell membrane integrity is dose dependent. The positive control amphotericin B showed leakage at MIC.

\section{Sublethal doses of CNB oil altered chitin distribution in C. albicans}

To determine morphological changes, we analyzed bright field images of $C$. albicans in stationary and logarithmic phases exposed to sublethal concentrations of CNB oil for $24 \mathrm{~h}$. Stationary phase C. albicans RSY150 cells exposed to sublethal CNB were oval and swollen, with distinct changes in chitin distribution, but with normal budding compared to control cells (Fig. 2a, d). Epifluorescence images of stationary phase control RSY150 show an even distribution of chitin around the cell wall and septal region (Fig. 2a, d). In contrast, cells treated with CNB oil at $62.5 \mu \mathrm{g} / \mathrm{mL}(1 / 2 \mathrm{MIC})$ had an increase in chitin content in the lateral cell wall and more intense staining at septal regions (Fig. 2a, d). This effect was absent at lower concentrations $(31.625 \mu \mathrm{g} / \mathrm{mL} ; 1 / 4 \mathrm{MIC})$ of CNB oil.

Similarly, the effects of CNB oil on metabolically active cells were distinct. Logarithmic phase cells exposed to $\mathrm{CNB}$ oil for $4 \mathrm{~h}$ at MIC and 1/2 MIC had intense chitin staining in the bud neck region and uneven lateral cell wall staining (Fig. 2b, e) compared to control cells that stained evenly at the bud and lateral wall. We also observed an increased frequency of elongated cells during exposure to $\mathrm{CNB}$ oil at MIC, which became less prominent at 1/2 MIC (Additional file 3: Figure S2a, b). The clinical isolate from blood, on the other hand, showed overall stronger staining than RSY150, with increased intensity at the bud neck upon exposure to CNB oil at MIC and 1/2 MIC (Additional file 4: Figure S3a). In contrast, the genital clinical isolate having a similar MIC to RSY150 showed a normal chitin distribution (Additional file 4: Figure S3b).

Based on the altered phenotype during $\mathrm{CNB}$ exposure at sublethal levels, we studied the impact of CNB on hyphal growth. During hyphal induction (10\% serum) in the presence of CNB oil, growing hyphae had intense chitin staining at their growing tips. The intensity of chitin staining was higher in cells treated at MIC and decreased progressively as 


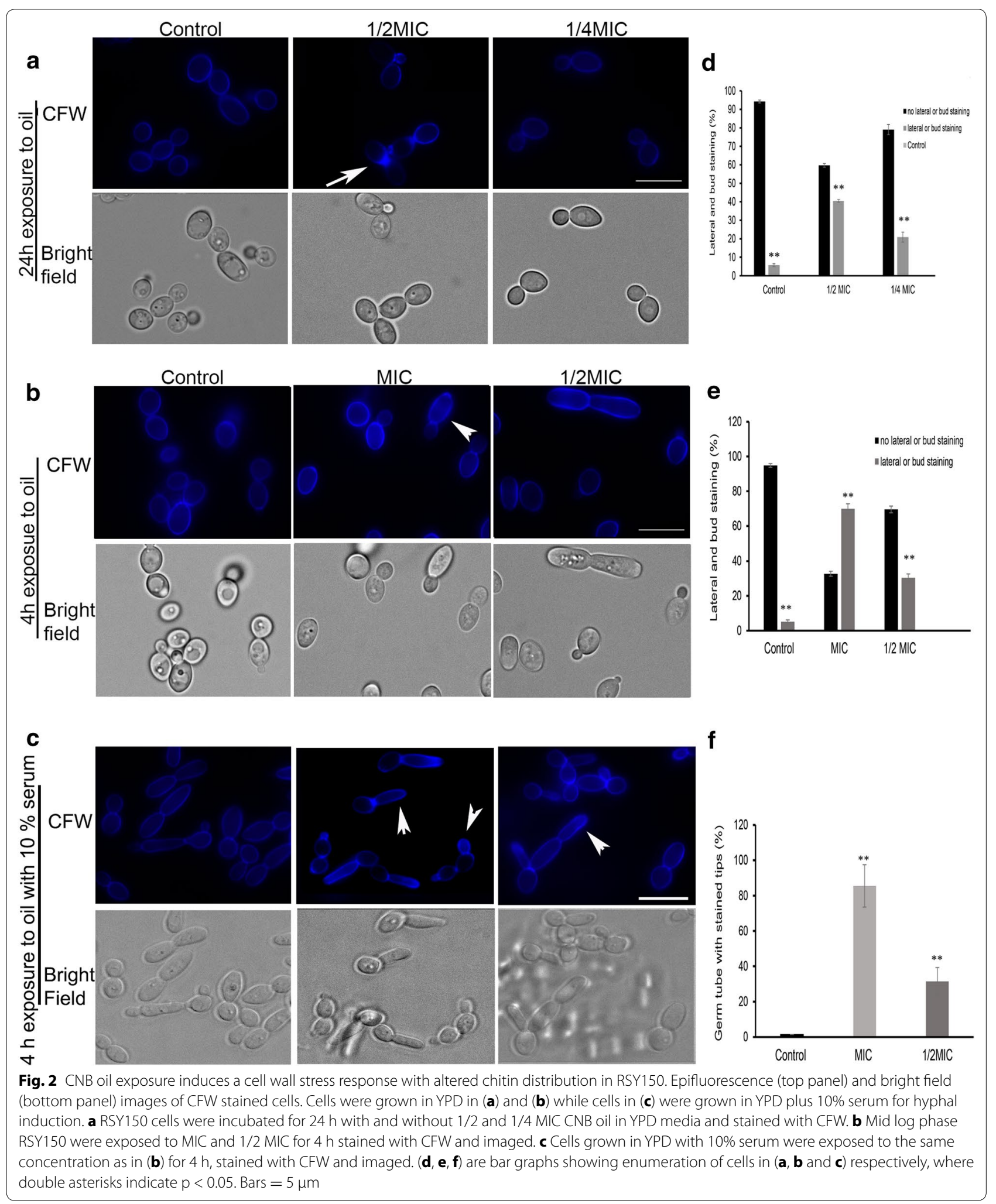


a function of $\mathrm{CNB}$ oil concentration, at 1/2 MIC (Fig. 2c, f). At $1 / 4$ MIC CNB the intensity of CFW staining was comparable to control, however hyphal width remained the same.

\section{Sublethal CNB oil induces cell wall remodelling in C. albicans}

AFM is a powerful tool for imaging ultrastructural changes at the cell surface and probing the associated biophysical properties. We chose $\mathrm{QI}^{\mathrm{TM}}$ mode, which records a large number of force curves $(n=16,536 ; 128$ pixel $^{2}$ resolution) for a detailed analysis. Representative $\mathrm{QI}^{\mathrm{TM}}$ images of RSY150 and a clinical isolate of C. albicans exposed to sub lethal concentrations of CNB oil, along with comparable controls, are shown in Fig. 3a-d. Changes in RSY150 and the clinical isolate after CNB treatment are summarized in Table 3. There was a clear difference between the CNB treated RSY150 and the clinical isolate, with $50 \%$ of the RSY150 cells showing leakage
Table 3 Various changes to C. albicans cells with CNB oil exposure revealed by AFM

\begin{tabular}{|c|c|c|c|c|c|}
\hline $\begin{array}{l}\text { C. } \\
\text { albicans } \\
\text { treated } \\
\text { with CNB } \\
\text { oil (total } \\
\text { \# of cells) }\end{array}$ & $\begin{array}{l}\text { Leakage } \\
\text { only }\end{array}$ & $\begin{array}{l}\text { Exfolia- } \\
\text { tion only }\end{array}$ & $\begin{array}{l}\text { Leakage } \\
\text { and exfo- } \\
\text { liation }\end{array}$ & $\begin{array}{l}\text { Surface } \\
\text { rough- } \\
\text { ness only }\end{array}$ & $\begin{array}{l}\text { Leakage } \\
\text { and sur- } \\
\text { face } \\
\text { roughness }\end{array}$ \\
\hline $\begin{array}{l}\text { RSY } 150 \\
\quad(n=24)\end{array}$ & 9 & 3 & 12 & - & - \\
\hline $\begin{array}{l}\text { Clinical } \\
\text { strains } \\
(n=21)\end{array}$ & 1 & 1 & 1 & 5 & 13 \\
\hline
\end{tabular}

Control cells had no visual changes

and exfoliation while the clinical isolate showed leakage with increased surface roughness. The exfoliation in these cells was usually limited to a small area on the cell

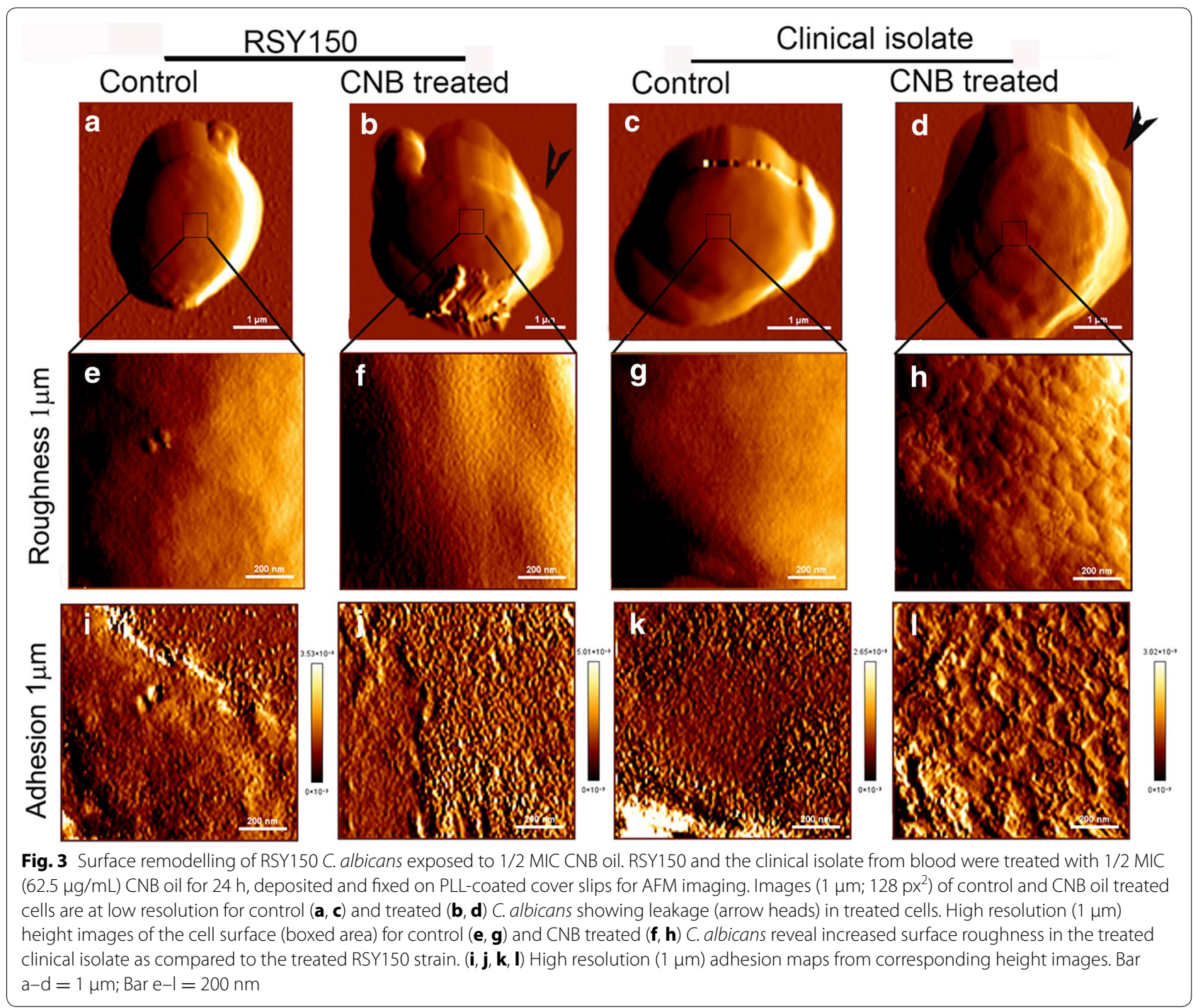


in the form of an aberration, while the rest of the surface showed little change. The clinical isolate exposed to CNB oil had rough cell surfaces, with or without leakage.

Candida albicans RSY150 and the clinical isolate displayed cell swelling and substantial cell wall structural and mechanical changes in response to CNB oil (Fig. 3). $\mathrm{QI}^{\mathrm{TM}}$ AFM of RSY150 $(\mathrm{n}=24)$ and a clinical isolate from blood ( $n=21)$ exposed to $1 / 2$ MIC of CNB oil showed obvious changes in cell volume, roughness, surface adhesion and cell wall elasticity.

Images of untreated RSY150 (Fig. 3a, c) revealed a normal oval cell with a height of $1.65 \pm 0.19 \mu \mathrm{m}$ and cell volume of $9.41 \pm 1.7 \mu \mathrm{m}^{3}$, which significantly $(\mathrm{p}<0.0001)$ increased to a height of $2.18 \pm 0.31 \mu \mathrm{m}$ and volume of $18.4 \pm 4.7 \mu \mathrm{m}^{3}$, respectively, following CNB oil treatment. The change in height $(2.07 \pm 0.29 \mu \mathrm{m}$ vs. control $1.83 \pm 0.27 \mu \mathrm{m})(\mathrm{p}=0.01)$ and volume (volume: treated $12.7 \pm 5.9 \mu \mathrm{m}^{3}$ vs. control $\left.16.2 \pm 4.7 \mu \mathrm{m}^{3}\right)(\mathrm{p}=0.047)$ of the clinical isolate was significant with CNB oil treatment, but less pronounced than that of RSY150 with similar treatment.

Control cells of both strains (Fig. 3e, g) revealed a smooth and homogeneous surface. There was a significant increase $(\mathrm{p}=0.015)$ in cell surface roughness $(5.4 \pm 1.0 \mathrm{~nm})$ of the clinical isolate following CNB oil exposure compared to control $(2.7 \pm 1.2 \mathrm{~nm})$, whereas the RSY150 (Fig. 3e-h) showed no significant change $(\mathrm{p}=0.2432)$ compared to control cells (treated $4.9 \pm 1.08 \mathrm{~nm}$ vs. control $3.52 \pm 1.77 \mathrm{~nm}$ ). These results are summarized in Table 4.

For accurate adhesive measurements of the cell surface, $1 \mu \mathrm{m} \mathrm{QI}^{\mathrm{TM}}$ AFM images (128 $\mathrm{px}^{2}$ resolution) were captured at the center top of the cells to eliminate artifacts from cell curvature. The adhesive properties of both RSY150 (treated $7.1 \pm 0.5 \mathrm{nN}$ vs. control $5.5 \pm 0.3 \mathrm{nN}$ ) and the clinical isolate (treated $7.6 \pm 0.6 \mathrm{nN}$ vs. control $5.7 \pm 0.4 \mathrm{nN}$ ) were significantly increased (RSY150 $\mathrm{p}=0.0016$, clinical isolate $\mathrm{p}=0.0025)$ in response to CNB oil. Figure $3 b, f, j$ and d, h, l shows whole cells, high resolution images, roughness and adhesive forces on the center top of RSY 150 and clinical isolates, respectively, grown for $24 \mathrm{~h}$ in the presence of sublethal

Table 4 Comparison of ultrastructural properties of RSY 150 and the clinical isolate from blood

\begin{tabular}{lrrrrr}
\hline & \multicolumn{2}{l}{ RSY150 } & & \multicolumn{2}{c}{ Clinical isolate } \\
\cline { 2 - 3 } & Control & \multicolumn{1}{c}{ Treated } & & Control & \multicolumn{1}{c}{ Treated } \\
\hline Height $(\mathrm{nN})$ & $5.5 \pm 0.3$ & $7.1 \pm 0.5$ & & $5.7 \pm 0.4$ & $7.6 \pm 0.6$ \\
Volume $\left(\mu \mathrm{m}^{3}\right)$ & $9.4 \pm 1.7$ & $18.4 \pm 4.7$ & & $16.2 \pm 4.7$ & $12.7 \pm 5.9$ \\
Roughness $(\mathrm{nm})$ & $3.5 \pm 1.8$ & $4.9 \pm 1.1$ & & $2.7 \pm 1.2$ & $5.4 \pm 1.0$ \\
\hline
\end{tabular}

$(62.5 \mu \mathrm{g} / \mathrm{mL}) \mathrm{CNB}$ oil. Exposure to CNB oil altered cell shape, increased the average cell volume and roughness (Fig. 3j, f), with a twofold increase in elasticity for RSY150 (treated 7.8 $\pm 0.9 \mathrm{GPa}$ vs. control $4.7 \pm 0.4 \mathrm{GPa}$ ) and the clinical isolate (treated $15.0 \pm 2.7 \mathrm{GPa}$ vs. control $8.1 \pm 0.7 \mathrm{GPa}$ ) compared to their respective controls. Table 5 shows a summary of these differences in RSY150 and the clinical isolate.

\section{CNB oil exposure increases C. albicans sensitivity to cell wall disrupting agents}

In order to determine whether cell wall integrity was compromised by CNB, RSY150 were exposed to cell wall perturbing agents $\mathrm{CR}$ and $\mathrm{CFW}$ at $1 / 2 \mathrm{MIC}$ and 1/4 MIC. Higher sensitivity, reflecting compromised cell wall integrity, was observed in CNB treated cells in comparison to control (Fig. 4a) at 1/2 MIC, progressively decreasing to $1 / 4 \mathrm{MIC}$ (Fig. 4b). As positive controls, we analyzed mutants lacking genes related to cell wall integrity and to wall organization and biogenesis for their sensitivity to CNB oil treatment. The mutants tested had the following knockouts: VPS28, a VPS factor required for vacuolar protein sorting; CRH11, encoding a GPIanchored cell wall transglycosylase; SSU81, encoding a function involved in oxidative stress, cell wall biogenesis, and morphogenesis; and DFG5, encoding an N-linked mannoprotein of the cell wall and membrane. All these mutants exhibit generalized sensitivity to CNB oil, with lower MIC than the wild type strain (CaSS1), further verifying an impact of CNB on cell wall integrity (Fig. 4c). The associated MIC decreased two-fold, from $125 \mu \mathrm{g} / \mathrm{mL}$ to $61.5 \mu \mathrm{g} / \mathrm{mL}$, for all mutants.

\section{CNB oil induces spindle defects in C. albicans at MIC and sub-MIC}

The RSY150 strain expressing both Tub2-GFP-and HtbRFP was imaged by LSCM to visualize the mitotic spindle in dividing cells exposed to CNB oil. In untreated cells, the spindle varied in length for the control RSY150 strain, but it consistently spanned the distance between mother and daughter cells (Fig. 5a) and nuclear migration was normal. In contrast, these well-defined mitotic spindles were missing in RSY150 cells exposed to CNB oil at MIC. Furthermore, Tub2-GFP fluorescence in these

\begin{tabular}{|c|c|c|c|c|}
\hline & \multicolumn{2}{|l|}{ RSY150 } & \multicolumn{2}{|c|}{ Clinical isolate } \\
\hline & Control & Treated & Control & Treated \\
\hline Adhesion (nN) & $5.5 \pm 0.3$ & $7.1 \pm 0.5$ & $5.7 \pm 0.4$ & $7.6 \pm 0.6$ \\
\hline Elasticity (GPa) & $4.7 \pm 0.4$ & $7.8 \pm 0.9$ & $15.0 \pm 2.7$ & $8.1 \pm 0.7$ \\
\hline
\end{tabular}




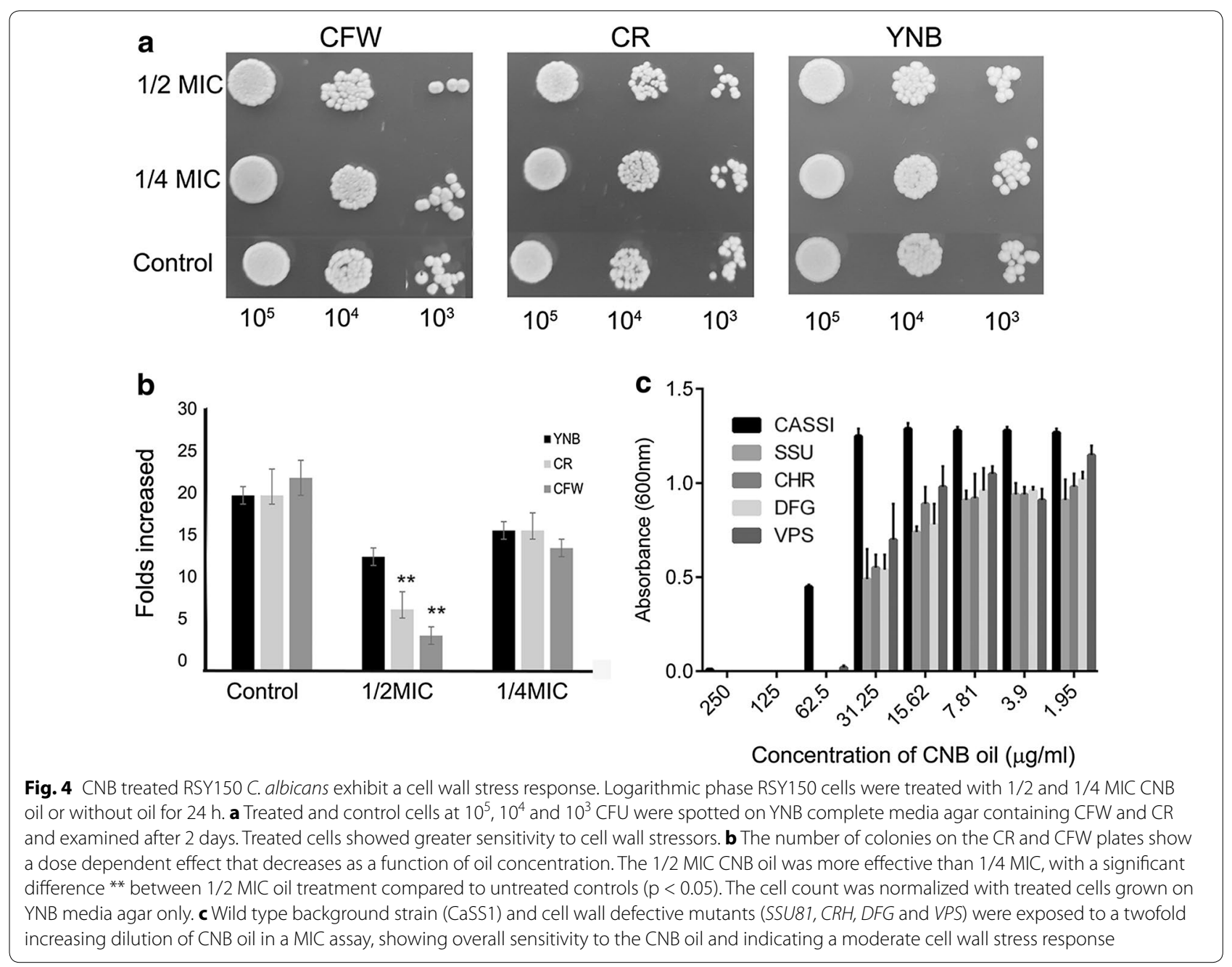

cells consistently failed to show the wild type pattern of spindle formation between mother and daughter cells (Fig. 5b). Instead, Tub2-GFP often had reduced fluorescence in cells undergoing nuclear division, with only several fluorescence spots visible, indicating disruption of the mitotic spindle. Cells exposed to sub MIC CNB oil had reduced spindle defects, with most of the cells in recovery phase and observed as fluorescent patches or aggregates of tubulin (Fig. 5c).

RSY150 cells grown to the mid logarithmic phase and exposed to oil for $4 \mathrm{~h}$ were imaged by LSCM to view patterns of nuclear division and tubulin distribution in the parent cells and the bud. Budding cells with a single nucleus were considered to be pre-mitosis, representing those in the G1 or S phase. Cells with nuclei traversing the parent and budding cells were considered to be in the anaphase stage of mitosis. Finally, cells having separate nuclei in both parent and budding cells were considered to be at a post-mitotic phase, G2/M. For RSY150 control cells, $52 \%$ of the population was in the G1 or S phase;
$36 \%$ of the cells had undergone mitosis; and the final $10 \%$ were in anaphase (Fig. 5b, c). On the other hand, RSY150 treated with MIC of CNB oil displayed noticeable differences in cell cycle distribution, with 39\% having not begun mitosis, $48 \%$ having completed mitosis, and $14 \%$ in anaphase, still undergoing nuclear division (Fig. 5c). Cells treated with $1 / 2$ MIC were at GI phase $(38 \%)$, whereas the dominant number of cells were at G2/M phase, with no change in the number of cells undergoing anaphase. Cells treated at MIC with CNB oil showed extended cells with pseudohyphal formation, however the effect was less pronounced in cells treated at $1 / 2 \mathrm{MIC}$, where large budding cells were observed (Additional file 3: Figure S2a, b). The data clearly indicate that CNB oil induces tubulin depolymerisation leading to cell cycle arrest at anaphase.

Cinnamaldehyde treated C. albicans showed similar morphological features to CNB oil treated cells (Additional file 5: Figure S4), with depolymerized tubulin, resulting in an absence of mitotic spindles. Overall the effect was more pronounced in cinnamaldehyde treated 


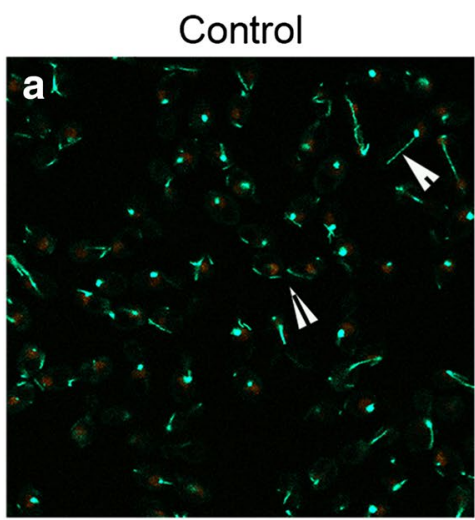

b

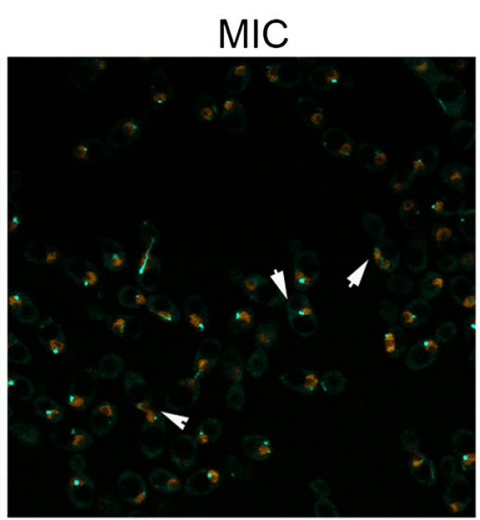

C

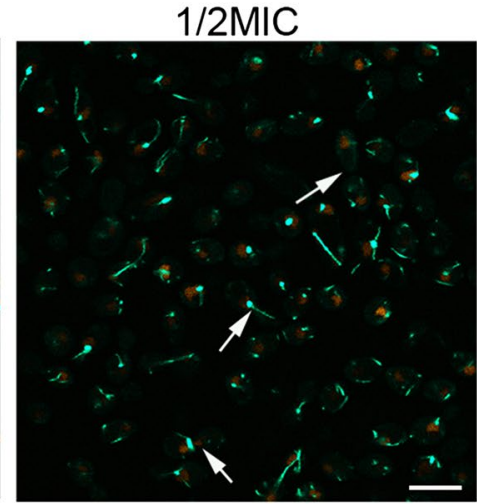

$\begin{array}{cccc} & \text { Before Mitosis Anaphase After Mitosis } \\ \begin{array}{c}\% \text { age } \\ \text { of cells }\end{array} & 52 & 10 & 36 \\ \text { Control } & 39 & 14 & 48 \\ \text { MIC } & 38 & 12 & 50 \\ \text { 1/2MIC } & 38\end{array}$

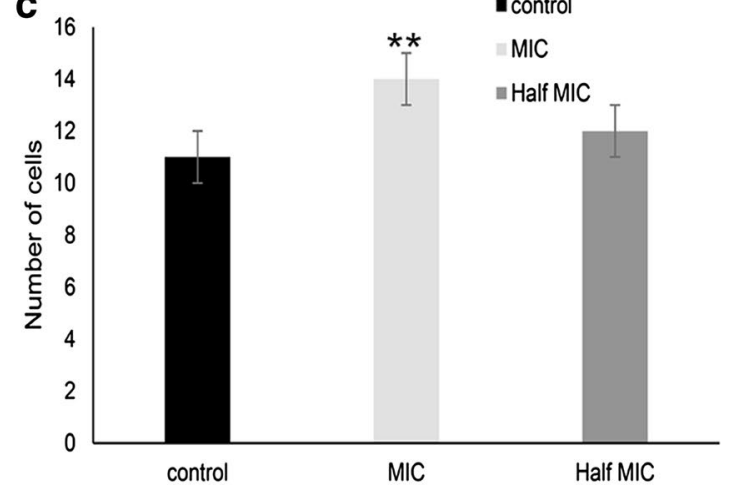

Fig. 5 CNB oil exposure in RSY150 C. albicans caused spindle defects in RSY150 and a delayed cell cycle. Mid logarithmic phase RSY150 cells were treated with MIC and 1/2 MIC oil for $4 \mathrm{~h}$ and imaged live by LSCM (Tub2-GFP $\lambda_{\mathrm{ex}}=488 \mathrm{~nm} ; \lambda_{\mathrm{em}}=512 \mathrm{~nm}$ and Htb-RFP $\lambda_{\mathrm{ex}}=543 \mathrm{~nm}$; $\lambda_{\mathrm{em}}=605 \mathrm{~nm}$ ). RSY150 were examined for nuclear and spindle localization in budding cells. a Spindle morphologies of MIC and 1/2 MIC CNB oil treated cells and untreated control. Control cells showed normal spindle formation during mitosis (arrow heads) whereas the MIC treated cells had a majority of dividing cells lacking a mitotic spindle (small arrow heads). Cells treated with 1/2 MIC of CNB oil had diminished spindle defects. Despite the spindle defect, the cells completed mitosis. Images are representative from three independent experiments. Bar $=5 \mu \mathrm{m}$. $\mathbf{b}$ Cell cycle analysis of cells treated with MIC and 1/2 MIC CNB oil and untreated controls. Of cells treated at MIC CNB oil, 14\% were in anaphase in comparison to $10 \%$ for control cells, whereas $12 \%$ of cells exposed to $1 / 2$ MIC CNB oil were in anaphase. c The number of cells counted for treated and control cells in anaphase were plotted. Double asterisks represent statistical significance $(p<0.05)$. For each treatment 250 cells were analyzed

cells as compared to those treated with CNB oil. Cells exposed to cinnamaldehyde at MIC showed a significantly increased percentage of cells in anaphase (15.8\%) as compared to control (9.6\%), whereas RSY150 cells exposed to linalool were arrested at the G1 phase of the cell cycle, as previously reported [20]. There was complete disruption of the cell wall at MIC after $4 \mathrm{~h}$, with cells having depolymerized tubulin compared to controls, however the cells showed some tubulin fluorescence at 1/2 MIC, with intact cell walls (Additional file 5: Figure S4).

\section{Discussion}

The cell wall of $C$. albicans is the first line of defense against the host immune system and toxic agents, modulating fungal interactions and maintaining cell integrity [52-55]. The C. albicans yeast cell wall contains three main components: mannoproteins ( 39\%), $\beta$-glucans $(\sim 59 \%)$, and chitin $(\sim 2 \%)$, that contribute to a highly dynamic molecular architecture which is continuously remodelled in response to cell surface interactions [53-55]. The cell wall integrity (CWI) pathway compensates for damage caused by environmental stress, signaling through the MAPK cascade to mediate cell wall biosynthesis and actin organization, regulating cell cycle progression and other necessary events [56-59]. In response to cell wall stressors, for example the antifungal drug caspofungin which is a non-competitive inhibitor of $\beta$-1,3-glucan synthase [60-62], activation of the CWI pathway can reinforce the cell wall by increasing chitin levels in Candida [63] and C. glabrata [64].

\section{Cell wall and membrane stress}

CNB oil treated RSY150 cells in the stationary phase had an irregular chitin distribution found on the lateral wall of budding cells (Fig. 2a). Such effects became 
pronounced in metabolically active cells grown in the presence of $10 \%$ serum (Fig. 2c, f), with intense chitin staining at the hyphal tip. Similar staining patterns have been reported for cells exposed to high sugar or salt concentrations [23], for which hypo-osmotic pressure induced chitin synthesis or polymerization at the growing hyphal tip. Consistent with this idea is the larger cell volume of RSY150 (Fig. 3) and sensitivity of the SSU18 mutant (Fig. 4c) exposed to CNB oil. Cell wall reinforcement with chitin in response to stress is a well-known phenomenon in yeast [62, 64-67]. It is known that most resistant clinical strains have a higher overall chitin content, reinforcing the cell wall and making them more resistant to cell wall targeted antifungals [68]. As expected, the metabolically active clinical isolate showed more chitin than RSY150 (Additional files 3, 4: Figures S2, S3) for both control and treated cells, confirming cell wall reinforcement in the clinical strain.

Chitin plays an important role in defining the cell wall nanomechanical properties [25, 27, 69], and $\beta-1,3 \mathrm{D}$-glucan is critical in maintaining cell shape, mechanical rigidity and resistance to osmotic pressure $[4,70]$. Exposure to CNB oil produced osmotically fragile, swollen cells with an uneven chitin distribution and increased elasticity, consistent with prior studies [25, 27, 52, 59]. The elasticity values reported in this study are high in comparison, reflecting cross linking from fixation [71]. Inhibition of $\beta$-1,3-D-glucan synthase by cinnamaldehyde in S. cerevisiae or by caspofungin in C. albicans results in reduced cell wall $\beta$-1,3-glucan [22] and increased cell wall chitin content, respectively [25]. Furthermore, mutants defective in chitin and $\beta$-glucan cross linking (chr1chr2A) have cell wall elasticity that varies with architecture and composition [60].

In addition to cell wall chitin and glucans, the surface of $C$. albicans is decorated with proteins called adhesins that play a pivotal role in cell communication, adhesion and microbial infection [72, 73]. Many adhesins are mannoproteins that are homogenously dispersed on the cell surface $[74,75]$. Cell wall stress, temperature variation, exposure to antifungal agents, host interaction and biofilm formation have been shown to alter the adhesive properties of cells $[67,76]$. Adhesive forces in this study are based on the interaction between the cell surface and the hydrophilic, negatively charged silicon nitride AFM tip. Exposure to CNB oil gave rise to a moderate increase in cell adhesion, which may be attributed to cell wall remodelling, as evidenced by concomitant changes in roughness. Changes in adhesion may reflect loss or rearrangement of adhesins, or reorganization of surface sugars $[25,27,29]$.

Cell wall stress was characterised not only by changes in chitin distribution and expression, but also polarized growth and moderate sensitivity to cell wall perturbing agents, leading to cell cycle arrest and fungal death [57]. Congo Red and Calcofluor White target chitin and $\beta-1,3-$ glucan synthases to produce a cytokinetic defect leading to cell cycle arrest $[77,78]$. A delayed or arrested cell cycle results in polarized growth with formation of pseudohyphal cells [79-81], as characterized by depolymerized microtubules [35, 82, 83]. Such a morphology was observed in $30 \%$ of the cell population exposed to CNB oil, along with defects in microtubule polymerization.

\section{Spindle defects}

Microtubules are central to cell division, forming the mitotic spindle and coordinating nuclear movement [82, 84, 85]. In Candida, the pre-mitotic movement of the nuclei through the bud neck and subsequent separation of nuclei are coordinated by microtubules [86]. In normal cells, nuclear division is complete when the buds are still small, such that larger budding cells are never observed without the nucleus [86]. In the control cells, two distinct subcellular microtubule structures were observed, one traversing the mother and budding cells and the other only in the mother cells. Anaphase and G2 cell cycle arrest, as well as a more pronounced filamentous growth, were apparent following CNB exposure (Fig. 5a, c). Cell cycle defects associated with microtubule perturbation were readily visualized in CNB treated RSY150 in which Htb-RFP and Tub2-GFP highlighted the nucleus and microtubules, respectively. Four hours following treatment with $\mathrm{CNB}$ at MIC, log phase cells had ablated mitotic spindles, observed as fluorescent patches or aggregates of tubulin (Fig. 5a). Large-budding cells had nuclear staining restricted to the mother cell (Fig. 5a, arrow). These results are consistent with previous observations in which tubulin polymerization inhibitors and $\Delta$ kar3/4kar3 mutants had similar phenotypes [35, 85]. We observe anaphase arrest in cells exposed to CNB at MIC, with $14 \%$ of the cells in anaphase as compared to $10 \%$ in the control, an effect which is reduced at $1 / 2 \mathrm{MIC}$. Cells treated at MIC cinnamaldehyde had $15 \%$ of cells in anaphase, slightly less than the $\Delta$ kar3/ $\Delta$ kar3 mutant that had $17 \%$ of cells in anaphase and exhibited polarized growth [35]. Kar3 may mediate microtubule sliding during nuclear fusion and possibly mitosis, interacting with spindle microtubules to produce an inwardly directed force on the poles that antagonizes the CIP8 and KIP1 outward force [36]. The $\Delta k a r 3 / \Delta k a r 3$ mutant (RSY35) is no more resistant to CNB oil than wild type, suggesting that Kar3 is not likely the target of CNB oil.

We observed pseudohyphal growth in CNB oil treated RSY150 at MIC, an effect which became less prominent at $1 / 2$ MIC, a common response of yeast experiencing cell wall stress [87]. For instance, toxins and chemicals 
that arrest cells in the $\mathrm{S}$ phase or mitosis display polarized growth due to activation of the CWI pathway [57, $88,89]$. The CWI pathway activates the MAPK cascade to manage stress, and its components are key elements in controlling the cell cycle. There are three MAPK pathways, namely; the pheromone response pathway, the high osmolality glycerol (HOG) pathway and the PKC1-mediated pathway [88, 89]. The increased sensitivity of the SSU81 knock-out mutant (Fig. 4c) suggests that the HOG pathway is activated in the presence of CNB oil. Under stress there is cross talk between these pathways and cell cycle checkpoints, resulting in a delayed cell cycle [88] and a mixture of yeast and pseudohyphal cells (Additional file 3: Figure S2a, b).

\section{Impact of CNB oil components}

The multisite impact of $\mathrm{CNB}$ oil can be attributed to both its major (cinnamaldehyde) and minor components. Cinnamaldehyde has been shown to compromise cell membrane and wall integrity [16], which we observe in this study along with a pronounced spindle defect and anaphase arrest. Minor components, which include limonene (2\%), eugenyl acetate $(0.6 \%)$, linalool $(3.9 \%)$ and benzyl benzoate $(0.6 \%)$, also contribute to CNB oil antifungal activity. The synergistic, additive or antagonist activity of these components to modify the overall effect of the oil has yet to be explored. However based on previous reports, these components target the cell membrane and modulate its function, including fluidity and permeability, leading to cell death [16-20]. Limonene (2\%) has been reported to affect the cell wall in S. cerevisiae [90, 91] and p-cymene (1.4\%) inhibits germ tube formation and alters cell membrane integrity [92]. Eugenyl acetate and linalool exhibit anti-virulence activity by inhibiting germ tube formation, and linalool has been reported to arrest cell cycle in the GI phase [20]. Such studies used higher (mg) concentrations of CNB oil components to produce their effects in comparison with their presence in CNB oil at only $0.6-5 \%$. There remains the possibility of synergies between the CNB oil components.

\section{CNB oil as an antifungal}

We propose that the main component of CNB oil, namely cinnamaldehyde $(75 \%)$, is responsible for the majority of the cell envelope defects observed in this study. The cell envelope mutants and cell stressor assays demonstrate that the cell wall is moderately affected, reinforced by chitin. Further, the sensitivity of all the cell envelope mutants indicates multiple targets for CNB oil, consistent with its chemical heterogeneity. Our data reports for the first time the depolymerisation of $\beta$ tubulin leading to cell cycle arrest at MIC of CNB oil. The mitotic spindle defect, a novel finding of this study, we attribute to cinnamaldehyde. The effect was strong at MIC and reduced at 1/2 MIC in cells exposed to either CNB oil or cinnamaldehyde. We propose that membrane disruption may lead to aberrant actin filaments, by virtue of actin's association with the membrane, and microtubule depolymerisation that ultimately disrupts the mitotic spindle, causing cell cycle arrest. This notion is supported by a finding in S. cerevisiae, for which both cytoplasmic microtubules and actin filaments are needed for spindle orientation [93], but further study is required to determine the role of actin in tubulin depolymerisation.

In summary, we suggest that $\mathrm{CNB}$ exerts its antifungal effect by targeting multiple cellular sites, including the cell wall, membrane and cell cycle machinery, ultimately leading to cell death induced by cell cycle arrest, a mechanism which requires further study.

\section{Conclusions}

In conclusion, the CNB oil used in this study consists of a mixture of terpenoids, phenols and aldehydes in varying amounts which target multiple cellular sites. Taken together, our data suggest essential oils may serve as antifungal alternatives or could be used in combination with synthetic antifungal agents to combat antifungal resistance.

\section{Additional files}

Additional file 1: Table S1. Chemical composition of CNB oil.

Additional file 2: Figure S1. Gas chromatogram of CNB oil. High deviation in $\mathrm{Rl}$ values for $\mathrm{E}$-cinnamaldehyde and a-caryophyllene result from its high concentration in the CNB oil, resulting in a non-Gaussian behaviour of the peak, and low concentration with late elution, respectively.

Additional file 3: Figure S2. (a) Cell cycle stress induced pseudohyphae in CNB oil exposed RSY150. Mid log phase RSY150 after $4 \mathrm{~h}$ exposure to CNB oil at MIC and 1/2 MIC, were stained with CFW. Images are epifluorescence (top panel) and bright field (BF; bottom panel). Bar $=5 \mu \mathrm{m}$. (b) Quantification of cells in control, MIC and 1/2 MIC from (a). Double asterisks represent $p<0.05$.

Additional file 4: Figure S3. (a) Clinical isolate exposed to CNB oil showed increased chitin content. The clinical isolate from blood at log phase after $4 \mathrm{~h}$ exposure to CNB oil at MIC and $1 / 2 \mathrm{MIC}$ were stained with CFW. Images represent CFW (top panel) and bright field (BF; bottom panel). Bar $=5 \mu \mathrm{m}$. (b) Genital clinical isolate with comparable MIC to RSY150 showed a normal chitin distribution.

Additional file 5: Figure S4. Spindle morphology of cinnamaldehyde and linalool treated C. albicans. Live LSCM of mid log phase cells after $4 \mathrm{~h}$ exposure to MIC and 1/2 MIC of cinnamaldehyde and linolool. Cinnamaldehyde treated C. albicans at MIC showed a similar spindle morphology of those treated with CNB oil at MIC, whereas linalool treated cells showed a complete absence of tubulin at MIC, with decreased cell size. At 1/2 MIC for both cinnamaldehyde and linalool, tubulin expression appeared as fluorescent spots near the nucleus. Bar $=5 \mu \mathrm{m}$.

Authors' contributions

ZS conducted the AFM experiments, was responsible for MIC determination and associated data analysis. AAG conceived the idea of using essential oils and provided intellectual input into the manuscript. TS designed all 
experiments and performed LSCM, cell wall stress experiments and wrote an initial draft of the paper. MW provided knock-out strains, JM clinical strains and each provided intellectual input into the data interpretation and manuscript. TESD wrote the initial research proposal, supervised the work, provided intellectual input and edited the manuscript. All authors read and approved the final manuscript.

\section{Author details}

${ }^{1}$ Department of Chemistry and Biochemistry, University of Regina, 3737 Wascana Parkway, Regina, SK, Canada. ${ }^{2}$ Microbiology and Immunology Department, Faculty of Pharmacy, Zagazig University, Zagazig, Egypt.

${ }^{3}$ Regina Qu'Appelle Health Region, Regina, SK, Canada. ${ }^{4}$ Centre for Structural and Functional Genomics, Concordia University, Montreal, QC, Canada.

\section{Acknowledgements}

We are grateful to Dr. Richard J. Bennett, Department of Molecular Microbiology and Immunology, Brown University, USA, for providing the RSY150 and RSY35 for this study. We thank Rebecca Jameson for the GC-FID and GC-MS analysis of the CNB oil and Cheghaf Madarati for images of glucanase treated C. albicans.

\section{Competing interests}

The authors declare that they have no competing interests.

\section{Consent for publication}

Not applicable.

\section{Ethics approval and consent to participate}

Committees from the following institutions approved this study: University of Regina's research ethics board and Regina Qu'Appelle Health Region. Samples were taken as part of routine care and anonymized, therefore according to ethical guidelines a wavier was granted for patient consent since this is no longer considered personal data.

\section{Funding}

This work was supported by National Science and Engineering Research Council (NSERC) grant to TESD (228206-07) and a NSERC Canada Research Chair to MW (950-228957). TESD was supported by the Canada Foundation for Innovation (CFI). TS was partially supported by the Faculty of Science and TESD's CFI IOF. ZS was partially supported by the Faculty of Graduate Studies and Research at the University of Regina.

\section{Publisher's Note}

Springer Nature remains neutral with regard to jurisdictional claims in published maps and institutional affiliations.

Received: 28 August 2017 Accepted: 16 January 2018

Published online: 09 February 2018

\section{References}

1. ClarkTA, Slavinski SA, Morgan J, Lott T, Arthington-Skaggs BA, Brandt $M E$, et al. Epidemiologic and molecular characterization of an outbreak of Candida parapsilosis bloodstream infections in a community hospital. J Clin Microbiol. 2004;42(10):4468-72. https://doi.org/10.1128/ JCM.42.10.4468-4472.2004.

2. Hajjeh RA, Sofair AN, Harrison LH, Lyon GM, Arthington-Skaggs BA, Mirza $S A$, et al. Incidence of bloodstream infections due to Candida species and in vitro susceptibilities of isolates collected from 1998 to 2000 in a population-based active surveillance program. J Clin Microbiol. 2004;42(4):1519-27.

3. Ostrosky-Zeichner L, Rex JH, Pappas PG, Hamill RJ, Larsen RA, Horowitz HW, et al. Antifungal susceptibility survey of 2,000 bloodstream Candida isolates in the United States. Antimicrob Agents Chemother. 2003;47(10):3149-54.

4. Odds FC, Brown AJ, Gow NA. Antifungal agents: mechanisms of action. Trends Microbiol. 2003;11(6):272-9.
5. Johnson MD, MacDougall C, Ostrosky-Zeichner L, Perfect JR, Rex JH. Combination antifungal therapy. Antimicrob Agents Chemother. 2004;48(3):693-715

6. Budzynska A, Sadowska B, Wieckowska-Szakiel M, Rozalska B. Enzymatic profile, adhesive and invasive properties of Candida albicans under the influence of selected plant essential oils. Acta Biochim Pol. 2014;61(1):115-21.

7. Goñi P, López P. Antimicrobial activity in the vapour phase of a combination of cinnamon and clove essential oils. Food Chem. 2009;1 16:982-9.

8. Ahmad A, Khan A, Manzoor N. Reversal of efflux mediated antifungal resistance underlies synergistic activity of two monoterpenes with fluconazole. Eur J Pharm Sci. 2013;48(1-2):80-6. https://doi.org/10.1016/j. ejps.2012.09.016.

9. Bassole $I H$, Juliani HR. Essential oils in combination and their antimicrobial properties. Molecules. 2012;17(4):3989-4006. https://doi.org/10.3390/ molecules 17043989.

10. Cowan MM. Plant products as antimicrobial agents. Clin Microbiol Rev. 1999;12(4):564-82.

11. Giordani R, Regli P, Kaloustian J, Mikail C, Abou L, Portugal H. Antifungal effect of various essential oils against Candida albicans. Potentiation of antifungal action of amphotericin B by essential oil from Thymus vulgaris. Phytother Res. 2004;18(12):990-5. https://doi.org/10.1002/ptr.1594.

12. Negri M, Salci TP, Shinobu-Mesquita CS, Capoci IR, Svidzinski TI, Kioshima ES. Early state research on antifungal natural products. Molecules. 2014;19(3):2925-56. https://doi.org/10.3390/molecules19032925.

13. Li Y, Nie Y, Zhou L, Li S, Tang X, Ding Y, et al. The possible mechanism of antifungal activity of cinnamon oil against Rhizopus nigricans. J Chem Pharmaceut Res. 2014;6(5):12-20.

14. Lopez P, Sanchez C, Batlle R, Nerin C. Solid- and vapor-phase antimicrobial activities of six essential oils: susceptibility of selected foodborne bacterial and fungal strains. J Agric Food Chem. 2005;53(17):6939-46. https:// doi.org/10.1021/jf050709v.

15. Pires RH, Montanari LB, Martins $\mathrm{CH}$, Zaia JE, Almeida AM, Matsumoto MT, et al. Anticandidal efficacy of cinnamon oil against planktonic and biofilm cultures of Candida parapsilosis and Candida orthopsilosis. Mycopathologia. 2011;172(6):453-64. https://doi.org/10.1007/s11046-011-9448-0.

16. Khan MS, Ahmad I, Cameotra SS. Phenyl aldehyde and propanoids exert multiple sites of action towards cell membrane and cell wall targeting ergosterol in Candida albicans. AMB Express. 2013;3(1):54. https://doi. org/10.1186/2191-0855-3-54

17. Musthafa KS, Hmoteh J, Thamjarungwong B, Voravuthikunchai SP. Antifungal potential of eugenyl acetate against clinical isolates of Candida species. Microb Pathog. 2016;99:19-29. https://doi.org/10.1016/j. micpath.2016.07.012.

18. Shreaz S, Bhatia R, Khan N, Muralidhar S, Manzoor N, Khan LA. Influences of cinnamic aldehydes on $\mathrm{H}(+)$ extrusion activity and ultrastructure of Candida. J Med Microbiol. 2013;62(Pt 2):232-40. https://doi.org/10.1099/ jmm.0.036145-0.

19. Taguchi Y, Hasumi Y, Abe S, Nishiyama Y. The effect of cinnamaldehyde on the growth and the morphology of Candida albicans. Med Mol Morphol. 2013;46(1):8-13. https://doi.org/10.1007/s00795-012-0001-0.

20. Zore GB, Thakre AD, Jadhav S, Karuppayil SM. Terpenoids inhibit Candida albicans growth by affecting membrane integrity and arrest of cell cycle. Phytomedicine. 2011;18(13):1181-90. https://doi.org/10.1016/j. phymed.2011.03.008.

21. Wang GS, Deng JH, Ma YH, Shi M, Li B. Mechanisms, clinically curative effects, and antifungal activities of cinnamon oil and pogostemon oil complex against three species of Candida. J Tradit Chin Med. 2012;32(1):19-24.

22. Bang KH, Lee DW, Park HM, Rhee YH. Inhibition of fungal cell wall synthesizing enzymes by trans-cinnamaldehyde. Biosci Biotechnol Biochem. 2000;64(5):1061-3.

23. Watanabe Y. A one-sided view of kinetochore attachment in meiosis. Cell. 2006;126(6):1030-2. https://doi.org/10.1016/j.cell.2006.09.005.

24. Alsteens D, Beaussart A, El-Kirat-Chatel S, Sullan RM, Dufrene YF. Atomic force microscopy: a new look at pathogens. PLoS Pathog. 2013;9(9):e1003516. https://doi.org/10.1371/journal.ppat.1003516.

25. El-Kirat-Chatel S, Beaussart A, Alsteens D, Jackson DN, Lipke PN, Dufrene YF. Nanoscale analysis of caspofungin-induced cell surface remodelling in Candida albicans. Nanoscale. 2013;5(3):1105-15. https://doi.org/10.1039/ c2nr33215a. 
26. El-Kirat-Chatel S, Beaussart A, Alsteens D, Sarazin A, Jouault T, Dufrene YF. Single-molecule analysis of the major glycopolymers of pathogenic and non-pathogenic yeast cells. Nanoscale. 2013;5(11):4855-63. https://doi. org/10.1039/c3nr00813d.

27. Formosa C, Schiavone M, Martin-Yken H, Francois JM, Duval RE, Dague E. Nanoscale effects of caspofungin against two yeast species, Saccharomyces cerevisiae and Candida albicans. Antimicrob Agents Chemother 2013;57(8):3498-506. https://doi.org/10.1128/AAC.00105-13.

28. Formosa C, Schiavone M, Boisrame A, Richard ML, Duval RE, Dague E. Multiparametric imaging of adhesive nanodomains at the surface of Candida albicans by atomic force microscopy. Nanomedicine. 2015;11(1):5765. https://doi.org/10.1016/j.nano.2014.07.008.

29. Francois JM, Formosa C, Schiavone M, Pillet F, Martin-Yken H, Dague E. Use of atomic force microscopy (AFM) to explore cell wall properties and response to stress in the yeast Saccharomyces cerevisiae. Curr Genet. 2013;59(4):187-96. https://doi.org/10.1007/s00294-013-0411-0.

30. Canetta E, Walker GM, Adya AK. Nanoscopic morphological changes in yeast cell surfaces caused by oxidative stress: an atomic force microscopic study. J Microbiol Biotechnol. 2009;19(6):547-55.

31. Alsteens D, Aimanianda V, Hegde P, Pire S, Beau R, Bayry J, et al. Unraveling the nanoscale surface properties of chitin synthase mutants of Aspergillus fumigatus and their biological implications. Biophys J. 2013;105(2):320-7. https://doi.org/10.1016/j.bpj.2013.05.040.

32. Adams RP. Identification of essential oil components by gas chromatography/mass spectorscopy. Miami: Allured Publishing Corporation; 2007.

33. Golmohammad F, Eikani MH, Maymandi HM. Cinnamon bark volatile oils separation and determination using solid-phase extraction and gas chromatography. Procedia Eng. 2012;42:247-60.

34. Joulain D, König WA. The atlas of spectral data of sesquiterpene hydrocarbons. Hamburg: Verlag, E.B; 1998.

35. Sherwood RK, Bennett RJ. Microtubule motor protein Kar3 is required for normal mitotic division and morphogenesis in Candida albicans. Eukaryot Cell. 2008;7(9):1460-74. https://doi.org/10.1128/EC.00138-08.

36. Endow SA, Kang SJ, Satterwhite LL, Rose MD, Skeen VP, Salmon ED. Yeast Kar3 is a minus-end microtubule motor protein that destabilizes microtubules preferentially at the minus ends. EMBO J. 1994;13(11):2708-13.

37. Roemer T, Jiang B, Davison J, Ketela T, Veillette K, Breton A, et al. Largescale essential gene identification in Candida albicans and applications to antifungal drug discovery. Mol Microbiol. 2003;50(1):167-81.

38. CaLS Institute. Performance standards for antimicrobial susceptibility testing: twenty-fourth informational supplement M100-S24. Wayne, PA: CLSI; 2014

39. Rajput SB, Karuppayil SM. Small molecules inhibit growth, viability and ergosterol biosynthesis in Candida albicans. Springerplus. 2013;2(1):26 https://doi.org/10.1186/2193-1801-2-26.

40. Hsu CC, Lai WL, Chuang KC, Lee MH, Tsai YC. The inhibitory activity of linalool against the filamentous growth and biofilm formation in Candida albicans. Med Mycol. 2013;51(5):473-82. https://doi.org/10.3109/1369378 6.2012 .743051

41. Dhamgaye S, Devaux F, Vandeputte P, Khandelwal NK, Sanglard D, Mukhopadhyay $\mathrm{G}$, et al. Molecular mechanisms of action of herbal antifungal alkaloid berberine, in Candida albicans. PLoS ONE. 2014;9(8):e104554. https://doi.org/10.1371/journal.pone.0104554.

42. Kumar A, Dhamgaye S, Maurya IK, Singh A, Sharma M, Prasad R. Curcumin targets cell wall integrity via calcineurin-mediated signaling in Candida albicans. Antimicrob Agents Chemother. 2014;58(1):167-75. https://doi. org/10.1128/AAC.01385-13.

43. Hammer KA, Carson CF, Riley TV. Antifungal effects of Melaleuca alternifolia (tea tree) oil and its components on Candida albicans, Candida glabrata and Saccharomyces cerevisiae. J Antimicrob Chemother. 2004;53(6):1081-5. https://doi.org/10.1093/jac/dkh243.

44. Li L, Aslam M, Rabbi F, Vanderwel MC, Ashton NW, Suh DY. PpORS, an ancient type III polyketide synthase, is required for integrity of leaf cuticle and resistance to dehydration in the moss, Physcomitrella patens. Planta. 2017. https://doi.org/10.1007/s00425-017-2806-5.

45. Kwolek-Mirek M, Zadrag-Tecza R. Comparison of methods used for assessing the viability and vitality of yeast cells. FEMS Yeast Res. 2014;14(7):1068-79. https://doi.org/10.1111/1567-1364.12202.

46. Pinto E, Hrimpeng K, Lopes G, Vaz S, Goncalves MJ, Cavaleiro C, et al. Antifungal activity of Ferulago capillaris essential oil against Candida, Cryptococcus, Aspergillus and dermatophyte species. Eur J Clin
Microbiol Infect Dis. 2013;32(10):1311-20. https://doi.org/10.1007/ s10096-013-1881-1.

47. Bhat SV, Booth SC, McGrath SG, Dahms TE. Rhizobium leguminosarum bv. viciae 3841 Adapts to 2,4-dichlorophenoxyacetic acid with "auxin-like" morphological changes, cell envelope remodeling and upregulation of central metabolic pathways. PLOS ONE. 2014;10(4):e0123813. https://doi. org/10.1371/journal.pone.0123813.

48. Bhat SV, Booth SC, Vantomme EA, Afroj S, Yost CK, Dahms TE. Oxidative stress and metabolic perturbations in Escherichia coli exposed to sublethal levels of 2,4-dichlorophenoxyacetic acid. Chemosphere. 2015:135:453-61. https://doi.org/10.1016/j.chemosphere.2014.12.035.

49. Klis FM, de Koster CG, Brul S. Cell wall-related bionumbers and bioestimates of Saccharomyces cerevisiae and Candida albicans. Eukaryot Cell. 2014;13(1):2-9. https://doi.org/10.1128/EC.00250-13.

50. Bapat P, Nandy SK, Wangikar P, Venkatesh KV. Quantification of metabolically active biomass using methylene blue dye reduction test (MBRT): measurement of CFU in about $200 \mathrm{~s}$. J Microbiol Methods. 2006;65(1):107-16. https://doi.org/10.1016/j.mimet.2005.06.010.

51. Painting K, Kirsop B. A quick method for estimating the percentage of viable cells in a yeast population, using methylene blue staining. World J Microbiol Biotechnol. 1990;6(3):346-7. https://doi.org/10.1007/ bf01201311.

52. Liu Y, Solis NV, Heilmann CJ, Phan QT, Mitchell AP, Klis FM, et al. Role of retrograde trafficking in stress response, host cell interactions, and virulence of Candida albicans. Eukaryot Cell. 2014;13(2):279-87. https://doi. org/10.1128/EC.00295-13.

53. Aguilar-Uscanga B, Francois JM. A study of the yeast cell wall composition and structure in response to growth conditions and mode of cultivation. Lett Appl Microbiol. 2003;37(3):268-74.

54. Chaffin WL. Candida albicans cell wall proteins. Microbiol Mol Biol Rev. 2008;72(3):495-544. https://doi.org/10.1128/MMBR.00032-07.

55. Free SJ. Fungal cell wall organization and biosynthesis. Adv Genet. 2013;81:33-82. https://doi.org/10.1016/B978-0-12-407677-8.00002-6.

56. Fuchs BB, Mylonakis E. Our paths might cross: the role of the fungal cell wall integrity pathway in stress response and cross talk with other stress response pathways. Eukaryot Cell. 2009;8(11):1616-25. https://doi. org/10.1128/EC.00193-09.

57. Heilmann CJ, Sorgo AG, Mohammadi S, Sosinska GJ, de Koster CG, Brul S, et al. Surface stress induces a conserved cell wall stress response in the pathogenic fungus Candida albicans. Eukaryot Cell. 2013;12(2):254-64. https://doi.org/10.1128/EC.00278-12.

58. Walker LA, Maccallum DM, Bertram G, Gow NA, Odds FC, Brown AJ. Genome-wide analysis of Candida albicans gene expression patterns during infection of the mammalian kidney. Fungal Genet Biol. 2009;46(2):210-9. https://doi.org/10.1016/j.fgb.2008.10.012.

59. Ene IV, Adya AK, Wehmeier S, Brand AC, MacCallum DM, Gow NA, et al. Host carbon sources modulate cell wall architecture, drug resistance and virulence in a fungal pathogen. Cell Microbiol. 2012;14(9):1319-35. https://doi.org/10.1111/j.1462-5822.2012.01813.x.

60. Imtiaz T, Lee KK, Munro CA, Maccallum DM, Shankland GS, Johnson EM, et al. Echinocandin resistance due to simultaneous FKS mutation and increased cell wall chitin in a Candida albicans bloodstream isolate following brief exposure to caspofungin. J Med Microbiol. 2012;61(Pt 9):1330-4. https://doi.org/10.1099/jmm.0.045047-0.

61. Denning DW. Echinocandin antifungal drugs. Lancet. 2003;362(9390):1142-51. https://doi.org/10.1016/S0140-6736(03)14472-8.

62. Walker LA, Munro CA, de Bruijn I, Lenardon MD, McKinnon A, Gow NA Stimulation of chitin synthesis rescues Candida albicans from echinocandins. PLoS Pathog. 2008;4(4):e1000040. https://doi.org/10.1371/journal. ppat.1000040.

63. Lee KK, Maccallum DM, Jacobsen MD, Walker LA, Odds FC, Gow NA, et al. Elevated cell wall chitin in Candida albicans confers echinocandin resistance in vivo. Antimicrob Agents Chemother. 2012;56(1):208-17. https:// doi.org/10.1128/AAC.00683-11.

64. Cota JM, Grabinski JL, Talbert RL, Burgess DS, Rogers PD, Edlind TD, et al. Increases in SLT2 expression and chitin content are associated with incomplete killing of Candida glabrata by caspofungin. Antimicrob Agents Chemother. 2008;52(3):1144-6. https://doi.org/10.1128/ AAC.01542-07.

65. Fortwendel JR, Juvvadi PR, Pinchai N, Perfect BZ, Alspaugh JA, Perfect $J R$, et al. Differential effects of inhibiting chitin and 1,3-\{beta\}-D-glucan 
synthesis in ras and calcineurin mutants of Aspergillus fumigatus. Antimicrob Agents Chemother. 2009;53(2):476-82. https://doi.org/10.1128/ AAC.01154-08.

66. Pfaller M, Riley J. Effects of fluconazole on the sterol and carbohydrate composition of four species of Candida. Eur J Clin Microbiol Infect Dis. 1992;11(2):152-6.

67. Popolo L, Gualtieri T, Ragni E. The yeast cell-wall salvage pathway. Med Mycol. 2001;39(Suppl 1):111-21.

68. Walker LA, Gow NA, Munro CA. Elevated chitin content reduces the susceptibility of Candida species to caspofungin. Antimicrob Agents Chemother. 2013;57(1):146-54. https://doi.org/10.1128/AAC.01486-12.

69. El-Kirat-Chatel S, Mil-Homens D, Beaussart A, Fialho AM, Dufrene YF. Single-molecule atomic force microscopy unravels the binding mechanism of a Burkholderia cenocepacia trimeric autotransporter adhesin. Mol Microbiol. 2013;89(4):649-59. https://doi.org/10.1111/mmi.12301.

70. Lesage G, Bussey H. Cell wall assembly in Saccharomyces cerevisiae. Microbiol Mol Biol Rev. 2006;70(2):317-43. https://doi.org/10.1128/ MMBR.00038-05.

71. Paul BC, El-Ganiny AM, Abbas M, Kaminskyj SG, Dahms TE. Quantifying the importance of galactofuranose in Aspergillus nidulans hyphal wall surface organization by atomic force microscopy. Eukaryot Cell. 2011;10(5):646-53. https://doi.org/10.1128/EC.00304-10.

72. Hoyer LL. The ALS gene family of Candida albicans. Trends Microbiol. 2001:9:176-80.

73. Lipke PN, Garcia MC, Alsteens D, Ramsook CB, Klotz SA, Dufrene YF. Strengthening relationships: amyloids create adhesion nanodomains in yeasts. Trends Microbiol. 2012;20(2):59-65. https://doi.org/10.1016/j. tim.2011.10.002

74. Glee PM, Cutler JE, Benson EE, Bargatze RF, Hazen KC. Inhibition of hydrophobic protein-mediated Candida albicans attachment to endothelial cells during physiologic shear flow. Infect Immun. 2001;69(5):2815-20. https://doi.org/10.1128/IAl.69.5.2815-2820.2001.

75. Ruiz-Herrera J, Elorza MV Valentin E, Sentandreu R. Molecular organization of the cell wall of Candida albicans and its relation to pathogenicity. FEMS Yeast Res. 2006;6(1):14-29. https://doi. org/10.1111/j.1567-1364.2005.00017.x.

76. Lopez-Ribot JL, Casanova M, Martinez JP, Sentandreu R. Characterization of cell wall proteins of yeast and hydrophobic mycelial cells of Candida albicans. Infect Immun. 1991;59(7):2324-32.

77. Roncero C, Duran A. Effect of Calcofluor white and Congo red on fungal cell wall morphogenesis: in vivo activation of chitin polymerization. J Bacteriol. 1985;163(3):1180-5.

78. Kopecka M, Gabriel M. The influence of congo red on the cell wall and (1-3)-beta-D-glucan microfibril biogenesis in Saccharomyces cerevisiae. Arch Microbiol. 1992;158(2):115-26.

79. Sudbery PE. Growth of Candida albicans hyphae. Nat Rev Micro. 2011;9(10):737-48. http://www.nature.com/nrmicro/journal/v9/n10/ suppinfo/nrmicro2636_S1.html.
80. Wightman R, Bates S, Amornrrattanapan P, Sudbery P. In Candida albicans, the Nim1 kinases Gin4 and Hsl1 negatively regulate pseudohypha formation and Gin4 also controls septin organization. J Cell Biol. 2004;164(4):581-91. https://doi.org/10.1083/jcb.200307176.

81. Bachewich C, Thomas DY, Whiteway M. Depletion of a polo-like kinase in Candida albicans activates cyclase-dependent hyphal-like growth. Mol Biol Cell. 2003;14(5):2163-80. https://doi.org/10.1091/mbc.02-05-0076.

82. Jacobs CW, Adams AE, Szaniszlo PJ, Pringle JR. Functions of microtubules in the Saccharomyces cerevisiae cell cycle.J Cell Biol. 1988:107(4):1409-26.

83. Mardon D, Balish E, Phillips AW. Control of dimorphism in a biochemical variant of Candida albicans. J Bacteriol. 1969;100:701-7.

84. Huffaker TC, Thomas JH, Botstein D. Diverse effects of beta-tubulin mutations on microtubule formation and function. J Cell Biol. 1988;106(6):1997-2010

85. Xu D, Jiang B, Ketela T, Lemieux S, Veillette K, Martel N, et al. Genomewide fitness test and mechanism-of-action studies of inhibitory compounds in Candida albicans. PLoS Pathog. 2007;3(6):e92. https://doi. org/10.1371/journal.ppat.0030092.

86. Finley KR, Berman J. Microtubules in Candida albicans hyphae drive nuclear dynamics and connect cell cycle progression to morphogenesis. Eukaryot Cell. 2005;4(10):1697-711. https://doi.org/10.1128/ ec.4.10.1697-1711.2005.

87. Berman J. Morphogenesis and cell cycle progression in Candida albicans. Curr Opin Microbiol. 2006;9(6):595-601. https://doi.org/10.1016/j. mib.2006.10.007.

88. Correia I, Alonso-Monge R, Pla J. MAPK cell-cycle regulation in Saccharomyces cerevisiae and Candida albicans. Future Microbiol. 2010;5(7):112541. https://doi.org/10.2217/fmb.10.72.

89. Correia IS. Editorial. Response to drugs and other chemical stresses in yeasts. OMICS. 2010;14(6):615-7. https://doi.org/10.1089/omi.2010.00ed.

90. Brennan TC, Turner CD, Kromer JO, Nielsen LK. Alleviating monoterpene toxicity using a two-phase extractive fermentation for the bioproduction of jet fuel mixtures in Saccharomyces cerevisiae. Biotechnol Bioeng. 2012;109(10):2513-22. https://doi.org/10.1002/bit.24536.

91. Miron D, Battisti F, Silva FK, Lana AD, Pippi B, Casanova B, et al. Antifungal activity and mechanism of action of monoterpenes against dermatophytes and yeasts. Revista Brasileira de Farmacognosia. 2014;24(6):660-7. https://doi.org/10.1016/j.bjp.2014.10.014.

92. Pina-Vaz C, Goncalves Rodrigues A, Pinto E, Costa-de-Oliveira S, Tavares C, Salgueiro L, et al. Antifungal activity of thymus oils and their major compounds. J Eur Acad Dermatol Venereol JEADV. 2004;18(1):73-8.

93. Hwang E, Kusch J, Barral Y, Huffaker TC. Spindle orientation in Saccharomyces cerevisiae depends on the transport of microtubule ends along polarized actin cables. J Cell Biol. 2003;161(3):483-8. https://doi. org/10.1083/jcb.200302030

\section{Submit your next manuscript to BioMed Central and we will help you at every step:}

- We accept pre-submission inquiries

- Our selector tool helps you to find the most relevant journal

- We provide round the clock customer support

- Convenient online submission

- Thorough peer review

- Inclusion in PubMed and all major indexing services

- Maximum visibility for your research

Submit your manuscript at www.biomedcentral com/submit 